\title{
Case Study of Law Majors in New Colleges and Universities with the Computer under the Background of Outstanding Talents
}

\author{
Shoubo Zhang \\ Cultural Tourism Department, Heihe College, Heilongjiang, China
}

Keywords: newly-established colleges and universities; law major; computer; case teaching

\begin{abstract}
The legal major as an important major in new undergraduate colleges, the practice teaching is different from the ordinary college teaching in cultural basis, self-learning ability, age, occupation of students, practice teaching, such as practice, experiment and social investigation shall be conducted. Based on the analysis of outstanding talents under the background of law specialty of new undergraduate colleges and universities by computer, the existing problems, the case teaching method, teaching method of simulated court are used to construct the distance education law practice teaching mode.
\end{abstract}

\section{Introduction}

Practice teaching of law professional is to practice and social investigation as the main content, for the realization of the applied talents and excellent talents under the background of the practical goal of our practical teaching is highly necessary for students can not only analyze legal issues is more important in the formation of law with the legal view of society the legal affairs occupation moral concept at work (Chen, 2008).

\section{The Problems Existing in the Practice Teaching of Law Major}

\subsection{The unclear teaching goal}

Using computer to practice the teaching of law major is mainly based on practice and social investigation, which is determined by the goal of teaching, and the goal of practice teaching is generally too high and too vague. For example, the practice teaching of law major in distance open education aims at training legal talents, and can grasp the basic knowledge while engaging in judicial practice, teaching or scientific research. Under the present situation of relatively poor running school resources, it is difficult to achieve the goal of too general and abstract training (He, 2006).

\subsection{The low teaching teacher level}

New undergraduate colleges open distance education law practice teaching needs enough high quality teachers in the full-time teachers unstable lack of practical experience of young teachers will not always practice through judicial experience. At the same time, the problems of school running, resources and funds restrict the quality of the practice teaching of law major in distance open education (Huo, 2008).

\subsection{The disjointed teaching method and the society}

As a discipline of law and research and practice, the traditional teaching method has always been the main teaching method, because only in this way can the latest legal provisions and the theory of law be transmitted. But the formation of legal thinking and legal methods to practice teaching, the reality is that the teacher read the student written exam back three step teaching form, have students reflect the practice teaching method and explains the problem to society. 


\section{Make Use of Computer to Reconstruct the Practice Teaching of Law Major}

\subsection{Strengthen and improve the public service function of the government}

You need to open the teaching practice of professional education law implementation plan, teaching syllabus and professional teaching practice guidance manual and other relevant documents to support teaching especially as practical teaching requires a legal case library in colleges has the condition to be arranged will usually have a mock court to give the students a relatively real the scene as a teaching site clear use of computer teaching practice of law professional organization and implementation of goals. But more schools and judicial departments, judicial institutions to establish a fixed practice base (Chen, 2007).

\subsection{The reconstruction of teaching guidance team of teachers with computers in practice of law major}

The law is to cultivate applied talents, and open education law professional teachers mostly young and without experience in judicial practice in the specific judicial practice, the lack of ability of team of teachers so they need urgent reconstruction schools on the one hand, the practice teaching experience of the judicial personnel hiring part-time teachers, on the other hand to achieve justice qualification of judicial experience of teachers, and to encourage law teachers lack experience in the judiciary exercise attachment allows teachers to contact the judicial practice to improve practical teaching ability (Xu, 2007).

\subsection{Apply advanced distance open education in law major practice}

The practice of law major in distance open education can be divided into two stages. Each stage should accept the ability to use with different teaching methods for different students can also choose across the stage of method in teaching the suitable learning ability of the uneven Distance Open Education students.

\subsection{Pre probation teaching method}

First, case method. Case teaching method, also called case law, refers to the practice teaching method focusing on the discussion and analysis of the cases of students. The open and distance education guides the teachers to collect and sort out the cases according to the relevant teaching contents, and then send them to the students as a teaching material for the students to read, analyze, and then let them learn

Student search, reading and comparative analysis of relevant cases. In the concrete way, we can spread the multimedia teaching method, insert the video in the teaching and so on, and guide the students to be interested in the case teaching.

Second, street law advisory. Street legal advice is required in open distance education law professional students use legal knowledge learned in University for the individual or unit law difficult to provide legal assistance in the "315" consumer protection day, "124" legal advocacy and some other important section to hold free advisory services $(\mathrm{Li}, 2007)$. Open distance education professional learning law should adhere to every year to organize a legal advisory activities through legal advice, let the students on, puts forward some methods to solve the problems of the consultation so as to enhance the knowledge of legal theory.

\subsection{Later probation teaching method}

First, the moot court method. Simulates the court teaching method, namely in the open and distance education law professional teachers guide students according to the typical case selection, so that the students were all the same as the role of the court in the trial of cases of flood simulation, the classroom teaching method of basic theories of law and judicial practice closely together. The basic theory of law students so the role of open and distance education of law students from the transformation of the judicial workers perspective change to go to school in the classroom has a more intuitive understanding, and get the maximum benefits in the (Qi, 2010). 
Second, social surveys. The purpose of social investigation is to enable students to understand, contact and understand society in a comprehensive way, and to look at and analyze social phenomena from various perspectives. The general social survey carried out during the holidays, teachers layout survey questions open distance education professional law before the final exam, students can understand the rural to the factories, and law related social phenomenon from the social reality, legal education at the end of words to students from the social investigation to the status of investigation report written according to the given social guidance teachers the survey results of students.

\subsection{The new undergraduate colleges and universities use the computer to carry on the law practice teaching system construction}

The concrete construction of the practice teaching system of law education includes the construction of practice teaching platform, the design of practical teaching module and the achievement of practical teaching objectives (i.e. the ability to train). Should increase the practice teaching platform, add other laboratory outside the original laboratory simulated court, at the same time to seek innovation in the practice of teaching content, students' ability to specific types of standard design, different modules are also rich in content, links and methods of practice teaching, to improve students' practice ability.

\subsection{The construction of practice teaching platform}

A lot of people think that law is not like science and engineering, there is no laboratory, so the practice teaching of law can only be carried out through classroom, extracurricular activities and campus culture. In fact, the practice teaching of law can not only have laboratories, but also build a certain number of laboratories, which mainly include the following aspects: moot court laboratory. Moot is the practice teaching of law teaching facilities for law students, both substantive law or procedural law study, have to carry through the simulation trial activity in simulated court to application and practice. At the same time, the court can also introduce formal court trial activities, build simulated courts with fixed sites, and purchase installation related equipment to meet the regular court trial activities of students. At the same time, as the platform of practice teaching, we should be able to provide experimental sites for practical teaching courses. Criminal investigation laboratory. The laboratory can provide experimental support for the course of legal science, the fact finding technology and the practice of prosecuting public prosecution. Specific construction will be criminal investigation simulation room, criminal photo room, darkroom, audio-visual editing room, criminal psychological testing laboratory, trace evidence laboratory, text inspection laboratory. Legal aid laboratory. A Legal Aid Centre will be set up to provide legal aid, arrange special sites for legal aid, purchase and install related equipment to meet the legal aid activities of students and the legal education of clinics. At the same time, it provides experimental teaching grounds for lawyer and notary practice, legal aid practice and enterprise economic law practice. Dossier reading laboratory. The laboratory can provide direct contact with the case of real life living opportunities for law students, allows students to learn a case from a lawyer or public security organs, procuratorate case intervention began the trial of the court even to implementation of the entire process, the student is a window to understand society. It also carries the teaching tasks of innovative experiment modules, such as legal documents writing contest, law recitation competition, case analysis meeting, etc. under the management and leadership of the laboratory.

\subsection{The construction of practical teaching content (practice teaching module)}

If the practical teaching wants to receive proper results, it is necessary to reform the content of practice teaching and make it diversified. This is the main system of special occupation ability to choose the employment direction of students to deepen the training aims to strengthen the students' occupation skill, enhance the employability and competitiveness. It mainly includes: trial practice module. This module is composed of trial practice, judge mediation, moot court and so on. Procuratorial practice module. This module consists of criminal investigation technology, prosecution practice, trial supervision practice and so on. Agent practice module. This module is 
composed of lawyer and notarization practice, enterprise legal practice training and legal aid course. Open innovation experiment module. The module is set up to meet the needs of modern experimental teaching, and to develop students' legal innovation ability and promote the development of "modular" practical teaching. This module takes institute innovation experiment project selection of students or students in self reporting open experimental project, through the legal document writing competition law, case analysis, recitation contest and other forms, to realize the cultivation of students' ability and innovation ability of the application of the law.

Specifically, each laboratory, as a practice teaching platform, undertakes the concrete operation of the practical teaching module, so as to achieve the goal of training the students' legal application ability. Training such as simulation laboratory undertakes court trial practice module teaching operation and the ability of students, training of criminal investigation laboratory undertakes the procuratorial practice module teaching operation and the ability of students, cultivating the legal aid agency laboratory undertakes module teaching operation and the ability of students, training file reading laboratory experiment module commitment to innovative teaching operation and the ability of students(Qi, 2010). Under each module, relevant practice courses are set up to cultivate students' legal application ability. As the trial practice module with the judicial practice, the judge and the court mediation simulation courses, training students to ascertain respectively the legal facts and evidence analysis, legal interpretation and legal reasoning and legal debate and negotiation ability. Open filed criminal investigation technology, prosecution and trial supervision practice practice courses procuratorial practice module, were cultured evidence investigation analysis ability, legal reasoning and legal debate with the facts and legal debates. Set up the practice of lawyer and notary agency, under the economic law and practice module enterprise legal aid practice courses, respectively, cultivate legal debate and reasoning ability, analysis of the legal debate and negotiation ability and evidence and legal reasoning. Open the law, case analysis and recitation contest legal writing game curriculum innovation experiment module, respectively, the cultivation of legal memory and understanding ability, the facts and legal reasoning and legal writing ability. In this way, all professional abilities required by law students are systematically and comprehensively developed. At the same time every laboratory platform as an independent unit, responsible for the laboratory related standard management work, including the leadership of the organization, teaching plan, teaching operation monitoring, practice teaching quality evaluation etc. Practice teaching plan for each item on each link to implement the specific content of the specific time, teaching, and formulate the corresponding evaluation standards and requirements, take practical course teachers must strictly implement, achieve the standardization requirements (Yong, 2006).

Build practice teaching platform in the laboratory in addition to the above, the practice teaching should be diversified, including not only the mock court, criminal investigation, legal aid and other sectors, can also practice practice bases (Trainee), social investigation, trial observation, case debate, legal advice, legal clinic the case, diagnosis and other aspects, multi angle, multi way, multi link to cultivate students' practical application ability (Zhu, 2008).

\section{Conclusion}

As is known to all, law teaching always has different methodology and follows different logic rules. In the actual teaching process, the abstract methods of induction, deduction, and analysis method, comparison method and combined method; specific methods are argument method, enumeration method, empirical method, diffusion method, question method, analysis method, insertion method, method of explaining etc. Each kind of method has its characteristic and the focal point, mutual influence, seepage and coordination, constituted the law teaching basic method system together. At the same time, practical teaching should adopt incentive mechanism to guide students to participate in the classroom and to diversify the participants in practice teaching. Practice is not only the teacher's teaching to students, but also the interactive teaching of students. It also includes the use of the social classroom to teach students. First, the interactive teaching practice between teachers and students. It mainly uses classroom (theoretical and practical) teaching to achieve the interaction between teachers and students. Secondly, interactive practice teaching 
among students. This enables students to communicate extensively between teachers and students, and turns students into another important part of practical teaching. Thirdly, interactive teaching between students and society. Take the students go out, please come in the way of experts, the organization of students social practice or invite experts and scholars in theory and practice to give lectures, to break the closed campus teaching environment, open teaching.

\section{Acknowledgement}

This thesis is General research project on teaching reform of higher education of Heilongjiang provincial education department in 2017; Project supported by legal profession leader of Heihe University, "Research on practical teaching of applied talents training of law major in local newly established universities under the training program of outstanding law talents", Project number is SJGY0214.

\section{References}

[1] Chen J., 2007. Legal protection mode of computer software and its protection scope on Nanchang University.

[2] Chen X., 2008. Computer software specialized legislation on East China University of politics and Law.

[3] He Y., 2006. Reflections on the current law education in China on research on Higher Education in China.

[4] Huo X., 2008. Practice and reflection of on Journal of Henan Institute of Political Science and Law Chinese Juris Master Education System.

[5] Li X., 2007. China on the legal protection of computer software on Mongolia University.

[6] Xu, L., 2007. Research on patent protection of computer software under on Dalian Maritime University.

[7] Qi H., 2010. Computer mode of practice compound legal talents training of administrative college several models of the on education in Liaoning.

[8] Qi, W., 2010. Law graduate with computer under the background of the practice teaching of law and society.

[9] Wang W., 2009. On the protection of business secrets of computer software. Hunan Normal University.

[10] Yong Z., 2006. An analysis of the educational reform of master of law, University.

[11] Zhu Z., 2008. On the present situation and reform of the master's degree in law education on Hebei University of law. 